\title{
The Roles and Challenges of Micro Finance in Women Empowerment: A Case Study in Oromia Credit and Saving Institution in West Shoa Zone, Ethiopia
}

\author{
Diriba Ayele Gebisa \\ Ambo University; Ethiopia \\ E-mail: dirayele@gmail.com \\ Aman Rikitu Dassa \\ Ambo University; Ethiopia \\ E-mail: aman.rikitu@gmail.com
}

\begin{abstract}
Empowerment of women has emerged as an important issue in recent times since women remained disadvantaged part of society for a long period of times. Empowerment of women facilitates development by the uplifting their economic, social and political status. Microfinance is proved to be the instrument to handle poverty that exists mostly in urban and rural areas of the country. It is treated as a key strategy in addressing development issues across the country since the last decade. This study basically attempts to analyze the roles and challenges of microfinance in women empowerment. A primary survey has been carried out to capture the realistic experiences from the women beneficiaries of Oromia Micro Credit and Saving Institution of West Shoa Zone branch. In order to address the objectives of the study, a mixed approach has been adopted and primary data were collected and analyzed using quantitative and qualitative analysis techniques. A total sample of 268 women customers' was selected using simple random sampling technique out of I3I6 target populations. Data collected from these respondents were analyzed and interpreted using percentage, weighted mean and mean ranking and the hypothesis was tested using the paired ttest. The findings showed that a significant number of clients had increased their income, saving, decision making and asset ownership rights and safeguarded themselves and their families from financial difficulties. Besides its role, the main challenging factors are unproductive usages of the loan, limited loan size, lack of training and follow up, low awareness and high-interest rate of the loan.
\end{abstract}

Keywords: Microfinance, Women's Empowerment, Credit and Saving.

\section{Introduction}

Microfinance has been recognized internationally as the modern tool to fight poverty and for rural development. Microfinance is effective in reducing poverty, empowering women and creating awareness which finally results in the sustainable development of the nation. A majority of microfinance programs target women with the explicit goal of empowering them. There are varying underlying motivations for pursuing women empowerment. Empowerment is an act of increasing the capacity of individuals or groups to make effective development and life choices and to transform those choices into desired actions and outcomes (Krishna, 2003). Women play great roles in the progress and development of societies by participating in the economic, political and socio-cultural practices. Though women in many societies contribute appreciable development inputs, however, they have little opportunities, they get unequal benefits from the activities they are involved such as lack of property and ownership rights in order to advance economically (Helm, I984). Women constitute about 50\% of the population, but women are among the poorest and the most vulnerable of the underprivileged and thus helping them should be a priority. Just over one-third of women are economically active worldwide (Mehra, 1997). In developing countries, women work longer hours, have fewer assets and earn three-quarters of the wages paid to men (Cheston, 2002). Microfinance has been seen as contributing not only to poverty reduction and financial sustainability but also to a series ways of economic empowerment, increased well-being and social and political empowerment for women themselves, thereby addressing goals of gender equality and empowerment (Mayoux and Hartl 2009, 8). Much concern has been given in recent decade with respect to economic empowerment of women through micro financial institutions because microfinance institutions are different from other financial institutions mainly because their services are directed towards the lower income group of the society. They are particularly established to meet the credit demand of poor households who are often not well-served by the organized formal financial market mainly due to lack of appropriate and adequate collateral (Stiglitz 1990). Similarly, in the past days, women were restricted to take part in economic, social and political activities and not given roles in decision making at her family. The situation was, even more, worsening in 
developing countries. Now the situation has been on the trend to change by the governments by taking affirmative action's to empower women in every aspect since empowering women economically received special attention as world leaders become committed to avoiding all factors that promote gender-based discrimination. One technique to empower women economically is through microfinance institution. Microfinance ideally enables the poor disadvantaged women to be accessed to financial services to overcome startup capital in doing income generating activities. Therefore, microfinance services lead to women's empowerment by positively influencing their socio-economic status and have the potential to make a significant contribution to gender equality and promote sustainable livelihoods and better working conditions for women. The broad purpose of the study was to examine the roles and challenges of microfinance institutions.

\section{Methods}

\section{Description of the study area}

The study was carried out in West Shoa Zone, Oromia, Ethiopia. The researcher used four districts for investigation. The selected locations are Ambo, Gedo, Guder and Ijaji towns. Geographically the zone's lies within latitudes of 8043I-9025I north and longitudes $3720-382^{\circ}$ east of the Greenwich meridian.

\section{Research Design}

To achieve the objectives of the study, a mixed approach has been used. The purpose of using the questionnaire was to gather sufficient data to assess the roles and challenges of microfinance in women empowerment.

\section{Sample size and sampling technique}

Respect to the sample size, a formula provided by Yamane (1967) was used to determine the minimum required sample size at $95 \%$ of confidence level, degree of variability 0.5 and level of precision $(\mathrm{e})=95$. From the total population of I3I 6 women beneficiaries in the study areas; 94, 66, 55 and 53 were proportionally taken from Ambo, Gedo, Ijaji, and Guder towns respectively and totally 268 respondents taken as a sample size of the study.

The sampling techniques used for this research were simple random sampling technique to select women clients as a sample of the study and the four districts purposively selected based on their proximity to Ambo town and their location convenience. The target population was accessed from documentation of the institutions' respective branches.

\section{Data sources}

The sources of data used for this research were the primary source. To achieve the stated objective of the research and to answer the research hypothesis primary data was used and this data collected through structured questionnaires from women beneficiaries of the microfinance.

\section{Data analysis}

Before analysis data were checked for consistency and completeness and then entered into a computer, and processed and analyzed quantitatively and qualitatively using SPSS Version 16.0. The output from SPSSS software was analyzed using descriptive statistics such as mean, standard deviations, frequency tables. Additionally, the researcher analyzed the hypothesis using the Paired t-test. Finally, the visualization of data in frequency tables, bar graphs, and pie charts will be made to facilitate presentation processes of the research.

\section{Result}

\section{Profile of women respondents}

Regarding the age of the respondents, the majority (72.63 percent) of the respondents is in the economically active working age. Age is an important variable with which affinity to social status is associated and the women of middle age are more enthus iastic than their older counter where they desire to earn a little more from alternative occupation to help their family (Prasad, I998). Respect to the marital statuses of the clients shows that 67 percent of them are married and research indicates that majority of married women in microfinance need for employment to meet household responsibilities and economic identity in their life (Kumaran, 1997).

\section{Type of business activities women clients are engaging}

Respect to the business type they are engaging, nearly one-third of them, 3I.34 percent of the clients were engaged in petty trading, like gulit (a petty trade along the roads), 25.75 percent of them were engaged in the service business, 27.24 percent of them were in the agricultural sector and 15.67 percent of them were in other sectors of activity. The result showed that the petty trading sub-sectors were a better sector of the economic activities in terms of absorbing and opening job opportunity for a large number of women clients in microfinance. 


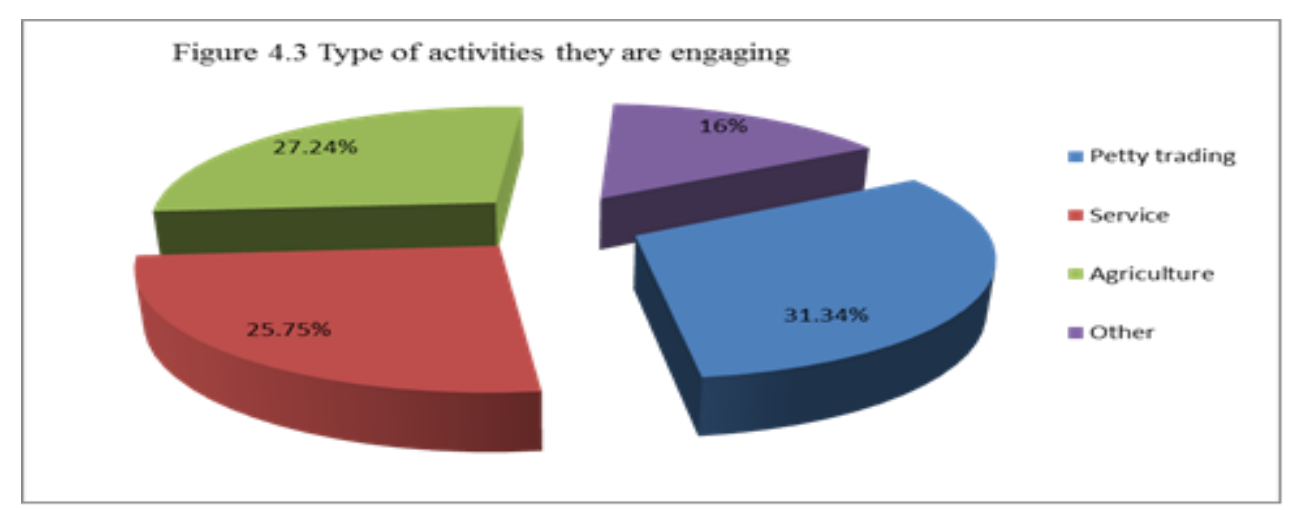

\section{Economic Empowerment \\ Effect of Micro Finance on income \\ Economic Empowerment}

\section{Effect of Micro Finance on income}

Respect to the response of the women clients to their prior and post income levels, 92(23.88\%) of the participants had no anything of income prior credit service but post credit service all of them started to earn above Birr 1000. Prior involvement large percentage, I68(62.68\%), of them had within the annual income of Birr I-I000 per year, but after involvement in the micro finance program none of them earned between Birr I-I000 per year.

The average incomes of each participant's prior involvement were Birr 559.7 with standard deviation of Birr 633 whereas the mean income post involvement in income generating activities increased to Birr 3,768.65 with standard deviation of is Birr 746 per year. There is a significant change on income levels of the participants post involvement in the micro finance loan program. The result confirms the finding of Asmelash (2003) and Arega(2016) and were credit provided to the poor had brought a significant income change.

\section{Impact of micro finance on saving}

Besides income another indicator for the benefit obtained by clients from the loans of the micro finance is change in saving capacity of the clients because savings are an important outcome indicator since increased savings can increase household investment in productive assets; smooth consumption in the event of emergency expenditures and increase women's empowerment if women have control over some savings. The result shows that prior involvement majority, $52.2 \%$, of them were in very low saving levels, however, post involvement the saving capacity of the clients in low saving levels category radically reduced to $7.1 \%$ and prior involvement $30.2 \%$ were in low category levels and $17.5 \%$ were in medium class. However, nearly half of the clients', $42.2 \%$, improve their saving capacity to medium levels.

The result is similar to the finding of (Pitt and Khandker,1998) where the poor have taken advantage of increased earnings to improve consumption and saving levels as a result of the intervention of microfinance.

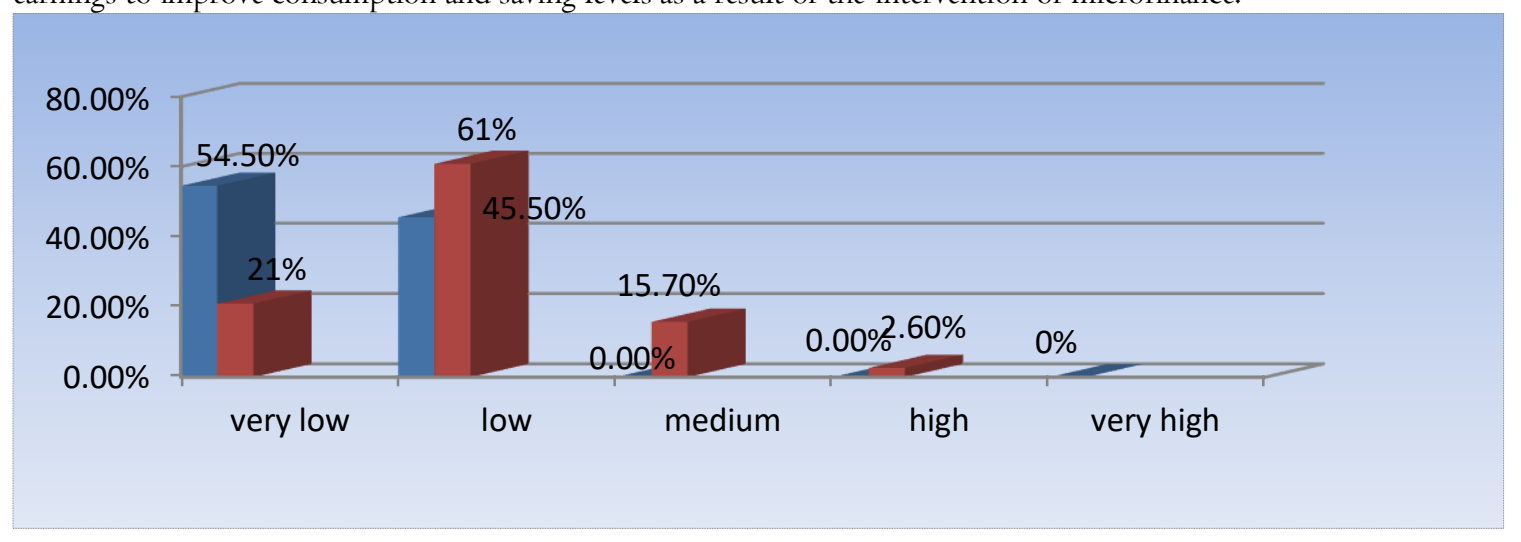

Figure. 2 Prior and Post Decision Making Ability of Women

The analyzed data relating to decision making ability of women prior and post involvement in the micro finance loan show reveals that significant difference observed in decision making ability between prior and after involvement in income generating 
program. Earlier involvement $73.75 \%$ of them unable to be involved in personal and family decision making but later on $83.75 \%$ of them capable to participate in decision making after involvement in income generating program. A great difference, 59.70 percent of improvement observed after involvement. The number of women failed to have decision making ability prior involvement sharply declined from 73.13 percent to 10.45 percent post involvement. The analyzed data revealed an overall improvement of 0.56 within the mean measurements, and $25.34 \%$ improvement in percentage. Besides mean and percentage, the standard deviation improved from 0.52 to 0.35 and coefficient of variations improved from 32.70 percent to II.90 percent, indicating consistency and improvement of the decision making ability of women at a family and individual level.

The result confirm the finding made by Whitehead (I990), Mbughuni (I994); Misana, (I995) and Mayoux (200I) that intra-household inequalities in making decision at house hold level can improved by the micro finance program.

\section{Hypotheses Testing}

To test proposed hypotheses whether the impact of microfinance on income, saving and asset ownership right of women beneficiary are significant or not a paired t-test for difference of mean has been used to test the significance. As shown in table 3 below, a paired t-test result revealed that microfinance clients had moderately higher mean annual income, saving, decision making and asset ownership right after joining the microfinance program than before as observed from a paired t-test statistics $(\mathrm{p}<0.05)$.

Since the probability values of all variable under considerations is less than $(p<0.05)$, we reject the null hypothesis and conclude that mean income, mean saving and asset ownership rights after joining micro finance is significantly higher than before. Thus, the result approves the descriptive result obtained before on page 7 regarding the impact of micro finance on income and saving levels of the clients.

Table 3 A paired t-tests of mean

\section{Challenges of women empowerment}

Besides the significant role of micro finance in women empowerment, there are various challenging factors that limit the empowerment potential of micro finance from analysis given on figure 3 . The main challenging factors from the mean analysis

\begin{tabular}{|c|c|c|c|c|c|c|c|}
\hline & \multirow[t]{2}{*}{ Items } & \multicolumn{3}{|c|}{ Paired Differences } & & \multirow[t]{2}{*}{ Df } & \multirow{2}{*}{$\begin{array}{l}\text { Sig. (2- } \\
\text { tailed) }\end{array}$} \\
\hline & & Mean & $\begin{array}{c}\text { Std. } \\
\text { Deviation }\end{array}$ & $\begin{array}{l}\text { Std. } \\
\text { Mean }\end{array}$ & Error & & \\
\hline Pair I & Income after - income before & .54478 & .90868 & & $.0555 \mathrm{I}$ & 267 & .000 \\
\hline Pair 2 & Saving after - Saving before & .77985 & 1.00934 & & .06166 & 267 & .000 \\
\hline Pair 3 & Decision making after - before & .82463 & I.I8788 & & .07256 & 267 & .000 \\
\hline Pair 4 & Asset ownership right after-before & .23134 & $\mathrm{I} .4374$ & & .0878 & 267 & .009 \\
\hline
\end{tabular}

are unproductive usage of the loan rather than using in productive sectors that add value to the loan taken, especially usage of the loan directly for consumption and debt repayment, the second challenging factor is limited loan size relative to the market conditions and capital required to start and get sustainable income from the limited loan size. The third ranked variable is lack of training and follows up and followed by low awareness, burden of the family job and high interest rate.

The result related to finding made by Hamida (2000) and Skarlatos (2004) were women's directly affected from micro finance benefit as a result of social discrimination, smaller loan sizes, difficult access to capital, low level of knowledge including literacy and numeric skills, lack of training and inadequate market knowledge.

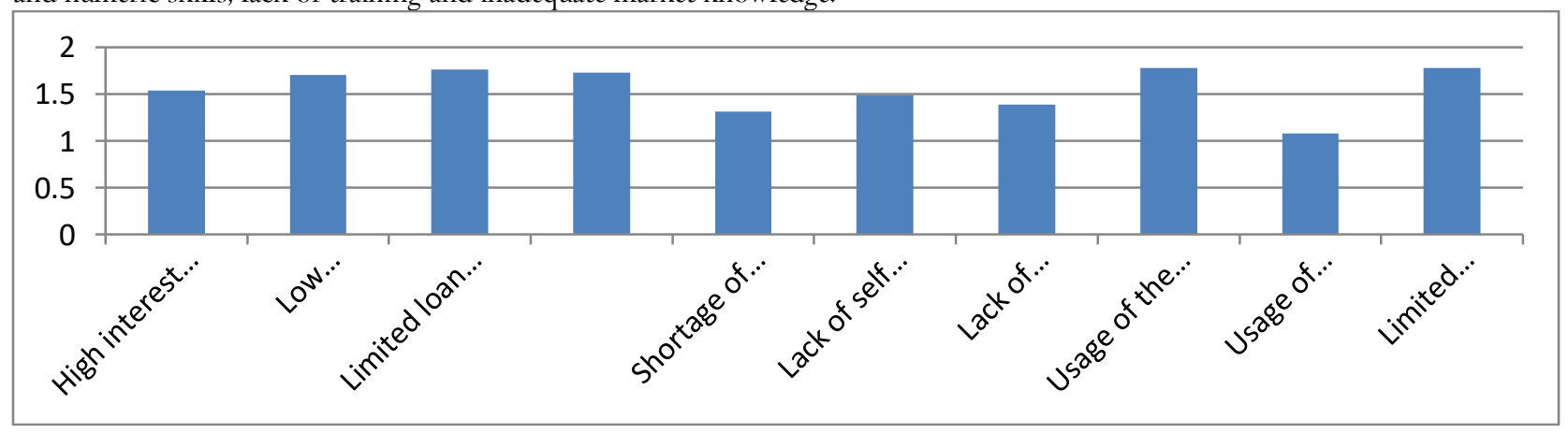

Figure. 3 Mean distribution of factors challenging women empowerment 


\section{Conclusion}

The objective of this study was all about the roles and challenges of microfinance in women empowerment. Microfinance has received considerable attention from the government's policymakers, donors' agencies, and even the academicians as an effective tool for boosting the socioeconomic of low-income people notably women. Regarding the impact of the microfinance on women empowerment, the study concludes that the credit service of the microfinance brought moderate change on income and saving of the women clients. In addition to improving clients' income and saving capacity, microfinance loans help women clients to enjoy asset ownership rights, decision making at family levels and in financing household welfare (like food, health and education, clothing and the likes). Loans services also help poor women to smoothen out income fluctuations and maintain families' consumption levels irrespective of the seasons. Furthermore, as a result of involvement in the microfinance program women beneficiaries made many changes and acquired assets. Therefore, the financial services of the microfinance increased income, saving, decision making and asset ownership rights and safeguard themselves and their families from the financial difficulties. A result of the t-test made at $(\mathrm{p}<0.05)$ also show there is a significant difference in income, saving and decision making of women clients prior and post involvement in microfinance loan.

There are different challenging factors that limit the potential of microfinance fully empowered by the microfinance services to be offered. The challenging factors are unproductive usage of the loan rather than using in productive sectors that add value to the loan taken, especially usage of the loan taken directly for consumption and debt repayment, the second challenging factor is limited loan size relative to the market conditions and capital required to start and get sustainable income from the limited loan size. The third-ranked variables that hinder women empowerment is lack of training and follow up, low awareness, the burden of the family job and high-interest rate.

\section{References}

Adongo, J. and C. Stork (2005), "Factors Influencing the Financial Sustainability of Selected Microfinance Institutions in Namibia", NEPRU Research Paper, No. 39

Aklilu, Y. (2002), "The Importance of Micro Finance Institutions in Developing Economies: Country Experience and Policy Implications to Ethiopia", NBE Staff Working Paper, ERD/SWP/005/2002.

Ahmadabad (200I), Role and Impact of Micro finance on poor - a study of clients using microcredit in two south Indian states: Friends of Women's World Banking (FWWB)

Ahmed, (20II). Rates on interest in the microcredit sector: comparing NGOs with commercial banks. In Attacking Poverty with Microcredit, S. Ahmed and M. Hakim, eds. Dhaka: University Press.

Asmamaw (2014): The Role of Microfinance Institutions in the Development of Small and Medium Size Businesses in ETHIOPIA: A Case Study in Amhara Credit and Saving Institutions, Journal of Business Administration and Management Sciences Research, Vol. 3(6), pp.I06-I20, June, 2014

Basic Research Journal of Business Management and Accounts.(20I4) The importance of microfinance and credit service for women economic development case study in Yirgalem Ethiopia. Available at: http//www.basicresearchjournals.org. 2014 pdf

Basic Research Journal of Business Management and Accounts Wolday Amha (2003), Microfinance Institutions in Ethiopia: Performance, Challenges and Role in Poverty Reduction, Occasional Paper No. 7, Addis Ababa, Ethiopia

Cheston, Susy and Lisa, Kuhn. (2002). Empowering women Through Microfinance. Washington: Published by UN IFEM for Micro-credit Summit 2002

Croom HELM (1984), Women and property, Women as property St. Martin's press New York CSA (2005), Central Statistical Agency of Ethiopia. Annual statistical Report: Addis Ababa

Diriba A (2014), Roles of NGOs in poverty alleviation. Unpublished MBA thesis, Jimma University of Ethiopia.

Getachew A. (2005) Women Economic Empowerment and Microfinance: A Review on Experiences of Awassa Women Clients in Gebrehiot A. (ed). AEMFI: Addis Ababa, Ethiopia

Getaneh Gobezie (2005) Regulating Microfinance in Ethiopia: Making it More Effective. Essays on Regulation and Supervision, No.3. Amhara Credit and Savings Institution (ACSI).

International NGO Journal Vol. 4 (IO) pp. 446-455, October 2009 Available online at http:// www.academicjournals.org/ingoj ISSN I993-8225 (C) 2009.

International Fund for Agricultural Development. (20II) Women empowerment and micro finance Rome, Italy Available at: www.ruralpovertyportal.org/20I Ipdf.

Lakew, B. (1998), " Micro enterprise Credit and Poverty Alleviation in Ethiopia: The Case the Project Office for the Creation of Small Scale Business Opportunities (POCSSBO) In Addis Ababa", Unpublished MSc. Thesis, Department of Economic, Addis Ababa University.

Mayoux, L., and M. Hartl (2009) Gender and rural microfinance: Reaching and empowering women - a guide for practitioners. IFAD report. Rome: International Fund for Agricultural Development. 
Mehra, A.K. (2003), 'The voluntary sector and political parties in India' in Ajay K. Mehra, Anil K Singh and Gert W. Kueck (eds.), Society, politics and the voluntary sector, Delhi.

Meron, A. (2009). Female-Headed Households and Poverty in Urban Ethiopia June 2009 Addis, Ababa University School of Graduate Studies, Pp. I5-I7.

One NGOs Contribution to Women's Economic Empowerment and Social Development in Zimbabwe MARIAJULIA* Jsda 014001300 pdf.

Tsegaye A (2006). 'Ethiopian Microfinance Institutions Performance Analysis Report', A

Tsehay T, Mengistu B (2002) 'The Impact of Microfinance Services among Poor Women in Ethiopia,' Association of Ethiopian Institutions, Occasional Paper No 6, August, 2002, Addis Ababa, Ethiopia

Wolday A. (2002). Occasional Paper No.2, Association of Ethiopian Microfinance Institution (AEMFI) Review of Microfinance Industry in Ethiopia: Regulatory Framework and Performance.

Yamane, T. (1967) Statistics: An Introductory Analysis, 2nd Ed., and New York: Harper and Row.

\section{Copyrights}

Copyright for this article is retained by the author(s), with first publication rights granted to the journal. This is an open-access article distributed under the terms and conditions of the Creative Commons Attribution license (http://creativecommons.org/licenses/by/4.0/). 